\title{
PENGARUH JENIS MEDIA TANAM DAN PUPUK ORGANIK CAIR TERHADAP PERTUMBUHAN DAN HASIL TANAMAN TOMAT ( Lycoppersium esculentum Mill.)
}

\author{
Fitriani Sefia ${ }^{1)}$, Tri Kurniastuti $^{2)}$, Palupi Puspitorini ${ }^{3)}$. \\ Program Studi Agroekoteknologi, Fakultas Pertanian, Universitas Islam Balitar \\ Jl. Majapahit No. 4 Sananwetan, Blitar \\ email : fitrianisefia186@gmai.com ${ }^{11}$ kurniastuti5@gmail.com ${ }^{2 /,}$ puspitorini.palupi@gmail.com ${ }^{3)}$
}

Submitted: 16 November 2021 Accepted: 26 Januari 2022 Approved: 27 Januari 2022

\begin{abstract}
ABSTRAK
Penelitian ini bertujuan untuk mengetahui Pengaruh Media Tanam dan Pupuk Cair Terhadap Pertumbuhan dan Hasil Tanaman Tomat Lycoppersium esculentum Mill. Varietas Corona terhadap Pupuk Cair Ratu Biogen. Penelitian ini menggunakan metode Rancangan Acak Kelompok (RAK) dengan 2 faktor dan 4 Level. Faktor utama yaitu: Tanah, Sekam, dan arang sekam.Tanpa Pupuk Organik Cair (X0), $2 \mathrm{~mL} / \mathrm{Liter}(\mathrm{X} 1), 4 \mathrm{~mL} / \mathrm{Liter}(\mathrm{X} 2), 6 \mathrm{~mL} / \mathrm{Liter}(\mathrm{X} 3)$. Para meter yang di amati meliputi tinggi tanaman, diameter batang tanaman, luas daun tanaman, jumlah daun tanaman, kulitas buah, jumlah buah, berat buah. Data analisis dengan menggunakan analisis ragam (ANOVA), jika berpengaruh dilanjutkan dengan uji Beda Nyata Terkecil (BNJ). Hasil penelitian berdasarkan hasil analisis ragam menunjukan bahwa : 2) perlakuan pemberian median dan pupuk cair (MX) berpengaruh Nyata terhadap pertumbuhan dan hasil tanaman Tomat meliputi semua parameter pengamatan yaitu mulai tinggi tanaman, Diameter batang tanaman, jumlah daun, luas daun, jumlah cabang, berat buah, dan jumlah buah, Kualitas Buah. Konsentrasi pemberian pupuk organik cair dengan media arang sekam , tanah (M3). Pupuk rganik Cair $2 \mathrm{~mL} /$ Liter Merupakan konsentrasi yang terbaik dengan menghasilkan nilai rata-rata tinggi pada semua parameter. Nilai terendah pada semua parameter ditunjukan dari konsentrasi tanpa pupuk organik cair).
\end{abstract}

Kata Kunci : Tomat, media tanam, pupuk organik Cair.

\section{ABSTRACT}

This study aims to determine the effect pf planting media and liquid fertilizer on growth and yield of tomato plans ( Lycopperium esculantium Mill) Corona varieties on ratu biogen liquid fertilizer. This study used a Randomized Block Design (RAK) method with 2 factors and 4 level. The main factors are : Soil, husk, and husk charcoal. Without liquid Organic Fertilizer (X0), 2 mL/ Liter (X1), 2 $\mathrm{mL} / \mathrm{Liter}(X 2), 6 \mathrm{~mL} / \mathrm{Liter}(X 3)$. The parameters observed included plant height, plant leaves, fruit quality, number of fruit, fruit weight. The data was analyzed using analysis of variance (Anova), if it had an effect, it was continued with the Least Significant Difference (BNJ). The results of the study based on the results of analysis of variance showed that: 2 the media treatment and liquid fertilizer ( $M X)$ had a significant effect on the growth and yield of tomato plasnts covering all observation parameters, namely plants height, plant stem diameter, numbrt of leaves, leaf area, number of brancher, fruit weight, and number of fruit, fruit quality. Concentration of giving liquid organic fertilizer with husk charcoal media, soil (M3). Liquid organic fertilizer $2 \mathrm{MI} /$ liter. Is the best concentration by producing a high average value on all parameters. The lowest value in all parameters is shown from the concentration without liquid organic fertilizer ( without liquid organic fertilizer).

Keyword : Tomato; liquid organic ferlitizer; growing media.

\section{PENDAHULUAN}

Tomat adalah salah satu varian sayuran buah yang pada kehidupan sehari-hati sudah sudah sangat dikenal oleh masyarakat Indonesia untuk dijadikan sebagai bahan pangan. Tomat dengan nama latin Lycopersicum esculentum Mill ini pertumbuhannya amat dipengaruhi oleh Jenis media bertanam yang dipergunakan. Media yang baik akan menjadikan unsur hara menjadi terjaga, kelembapan terjamin serta drainase terawat. Prayugo (2007) dan Riyanti (2009) mengemukakan bahwa jenis media tanam yang ideal harus mempunyai kemampuan dalam mengikat air dan menyediakan unsur hara yang akan dibutuhkan dalam perkembangan tanaman, terlebih lagi dapat memberikan kontrol 
terhadap drainase atau kelebihan air serta mempunyai sirkulasi dan menyediakan unsur aerasi atau udara dengan baik, bisa mempertahankan tingkat kelembapan disekir bagian akar tanaman, dan mempunyai ketahanan yang tinggi (tidak mudah lapuk atau rapuh). Bahan organik yang bisa dipergunakan sebagai media tanam adalah media sekam padi dan media hasil pembakaran (sekam bakar).

Tomat merah memiliki segudang manfaat diantaranya sebagai bahan tambahan masakan, sebagai bahan campuran dalam berbagai olahan industri makanan dan juga minuman, dan juga bisa dimanfaatkan dibidang farmasi dan kosmetik. (Setiadi, 2008). Tingkat poduktivitas buah tomat di wilayah kota besar menurut data BPS (2012) memaparkan data bahwa produksivitas tanaman tomat pada kurun waktu tahun 2013 mencapai angka $3,76 \mathrm{~kg}$ per ton. Kendala yang biasanya dihadapi dalam proses budidaya tanaman tomat yakni, benih yang dipergunakan dalam budidaya merupakan benih yang tidak unggul, teknik berbudidaya tanaman tomat belum mencapai tingkat intensifitas yang diharapkan, dan tingkat kesuburan tanah (media tanam) masih terbilang rendah.

Faktor lain yang turut menjadi penghambat atau kendala yang dihadapi oleh para petani adalah tingkat produksi tomat yang terjadi pada para petani masih terbilang rendah atau kurang. Hal tersebut merupakan akibat dari ketersedian unsur hara yang berada di dalam tanah semakin menurun selama fase regenerasi tanam tomat. Dalam hal ini yang harus diperhatikan adalah penggunaan pupuk kimia secara terus menerus tanpa adanya kesadaran akan dampak kedepannya sehingga menggunakan pupuk organik cair dalam proses budidaya tomat menjadi jawaban dalam meningkatkan produksi tanaman tomat dengan efek jangka panjang.

Penggunaan pupuk organik cair juga mengandung manfaat dalam proses penyerapannya yang lebih mudah dibandingkan dengan pupuk kimia. Kebutuhan tanaman akan nutrisi penunjang perkembangannya akan lebih terpenuhi baik yang diserap melalui lubang stomata ataupun melalui akar tanaman. Hal tersebut sangat sesuai dengan apa yang telah dikemukakan oleh Surtina (2009), penggunaan pupuk organik berjenis cair akan bisa dengan gampang diserap oleh varietas tanaman sehingga faktor penggunaan pupuk akan terjadi dengan sangat efisien. Selain itu, pemberian pupuk organik cair bagi tanaman juga bisa merekontruksi sifat kimia, biologis, dan fisik tanah, tingkat produksi hasil tanaman menjadi meningkat, kualitas produk tanaman menjadi terjaga (Parman, 2007). Pentingnya peran serta media tanam dalam mengumpulkan bahan dan substrat tempat pertumbuhan benih melalui penyebaran atau ditanam juga harus diperhatikan. Media tanam bisa berupa percampuran dari beraneka bahan muapun satu jenis media saja asalkan mampu memenuhi prasyarat yang diantaranya : cukup baik dalam mengikat air, memiliki sifat porous sehingga air yang digunakan untuk menyiram tanaman tidak menjadi genangan (becek), tidak memiliki sifat toksit (racun) terhadap tanaman, dan yang terpenting adalah media tanam tersebut mempunyai kandungan unsur hara yang tinggi sehingga sangat diperlukan terhadap pertumbuhan tanaman. (Alatas, 2013)

Pemberian pupuk organik berjenis cairan pada tanaman bisa memberikan peningkatan pada kualitas tersedianya dan penyerapan unsur hara utamanya unsur hara dengan unsur $\mathrm{N}$ yang menjadi keperluan penting bagi tanaman. Dengan demikian, tanaman bisa lebih memacu pertumbuhan vegetatifnya. Seperti dikemukakan oleh Amilia (2011) yang menyatakan bahwa unsur hara dengan unsur $\mathrm{N}$ oleh tumbuhan diperlukan dalam proses pembentukan klorofil di daun tanaman yang tentunya diperlukan pada kegiatan berfotosintesis serta memberikan dorongan pada tahap tumbuhnya vegetatif tanaman.

Seperti yang sudah dijelaskan sebelumnya peran pupuk organik cair bagi tanaman tomat memang sangat bermanfaat, selain itu, pupuk organik cair juga bisa meningkatkan hasil panen tanaman tomat. Pemberian media yang baik pada tanah akan bisa memperbaiki drainase tanah, granulasi tanah, dan aerasi. Penggunaan pupuk organik cair sangat diperhitungkan karena bisa memperbesar kemampuan tanah dalam menyerap air, memperbaiki kontruksi tanah baik fisik maupun biologisnya, serta tidak akan mengakibatkan polusi zat kimia pada tanah dan air.

Pemakaian pupuk organik cair juga harus didukung dengan media yang digunakan dalam proses pertanian tomat, penggunaan sekam dan arang sekam menjadi kelebihan tersendiri karena bersifat organik. Hal tersebut sebagai upaya pada peningkatan berbagai unsur hara yang terkandung pada tanah tempat bertumbuhnya tanaman. Selaras dengan penelitian yang telah dilakukan oleh Anonim (2011) yang mengemukakan sebuah hasil dimana peneraapan dan penggunaan 
media organik serta pupuk organik berjenis cair pada tanaman tomat (Lycopersicum esculentum L.) mempunyai pengaruh yang signifikan terhadap perkembangan tanaman tomat baik pertumbuhan yang vegetatif maupun generatif. Pada penelitian ini penulis mengemban tujuan untuk memperoleh pengetahuan tentang penyebab jenis media tanam dan pupuk orgaik cair terhadap laju pertumbuhan dan hasil panen tanaman tomat atau dengan nama latin (Lycopersicum esculentum $\mathrm{M}$.)

\section{METODOLOGI PENELITIAN}

Penelitian yang kami lakukan ini dilaksanakan di bulan Februari-April 2021 di Desa Karangsono Kecamatan Kanigoro, Kabupaten Blitar. Penelitian ini dilakukan di tempat yang memiliki tinggi $300 \mathrm{~m}$ dpl dan bersuhu kisaran $30-32^{\circ} \mathrm{C}$.

Metode yang dipergunakan pada penelitian ini menurupakan penerapan dari metode Rancangan Acak Kelompok atau dapat disingkat RAK yang tersusun dengan sedemikian rupa secara Split-Plot dengan 2 buah faktor yang terus dijadikan berulang dengan ketentuan banyak ulangan 3 kali. Pada 2 buah faktor itulah diperoleh data sebanyak 12 kombinasi perlakuan, sehingga diketahui ada 36 satuan kombinasi perlakuan. Faktor 1 Jenis Media yang tersusun atas 3 level, yakni ; M1: Media Tanah, M2: Media Sekam, M3 merupakan Arang Sekam. Kemudian faktor ke 2 adalah Pupuk organik cair Ratu Biogen yang tersusun atas 4 level, yakni; X0 : tanpa pupuk berjenis organik cair, $\mathrm{X} 1$ : pupuk organik cair $2 \mathrm{~mL} /$ Liter, $\mathrm{X} 2$ : pupuk berjenis organik cair dengan banyak $4 \mathrm{~mL} /$ Liter, $\mathrm{X} 3$ : pupuk berjenis organik cair dengan banyak 4 $\mathrm{mL} /$ Liter.

Data hasil dari kegiatan mengamati yang telah didapatkan kemudian dianalisis sedemikian rupa dengan menggunakan analisis ragam atau dikenal dengan sebutan uji $\mathrm{F}$ dengan taraf sebanyak $5 \%$. Kemudian jika hasil uji $F$ didapatkan keterbedaan yang signifikan antar perlakuan, dengan begitu akan diteruskan dengan sebuah uji banding antar semua perlakuan mempergunakan konsep Beda Nyata Jujur (BNJ).

\section{HASIL DAN PEMBAHASAN}

\section{Tinggi Tanaman (cm)}

Hasil Penen dengan mengacu pada analisis ragam diperoleh data yang mengintegrasikan bahwa terdapat interaksi antara ragam media dan pemilihan $\mathrm{POC}$ berpangaruh nyata (signifikan) bagi ketinggian tanaman tomat di usia $7 \mathrm{Hst}$, kemudian pada $14 \mathrm{Hst}$, kemudian $28 \mathrm{Hst}$, kemudian $42 \mathrm{Hst}$, terakhir pada usia 49 Hst serta memiliki pengaruh sangat singnifikan terhadap tinggi tanaman di usia 21 Hst dan tidak terjadi interaksi secara nyata di umur $35 \mathrm{Hst}$. Secara terpisah pemberian dosis pupuk kompos memiliki pengaruh nyata di umur $7 \mathrm{Hst}$.

Tabel 1. Rata-rata tinggi tanaman tomat sebagai akibat dari penerapan pemberian jenis media tanam serta POC

\begin{tabular}{|c|c|c|c|c|c|c|}
\hline \multirow{2}{*}{ Perlakuan } & \multicolumn{6}{|c|}{ Rerata tinggi Tanaman (HST) } \\
\hline & $7 \mathrm{Hst}$ & $14 \mathrm{Hst}$ & $21 \mathrm{Hst}$ & $28 \mathrm{Hst}$ & $42 \mathrm{Hst}$ & $49 \mathrm{Hst}$ \\
\hline M1X0 & $16,20 \mathrm{ab}$ & $20,58 \mathrm{a}$ & $28,79 a$ & $59,14 \mathrm{ab}$ & $71,78 \mathrm{ab}$ & $76,33 \mathrm{ab}$ \\
\hline M1X1 & $15,59 a$ & $21,56 \mathrm{a}$ & $30,66 \mathrm{bc}$ & $61,33 a b$ & $73,11 a b c$ & $76,22 a b$ \\
\hline M1X2 & $15,44 \mathrm{a}$ & $21,10 a$ & $30,93 \mathrm{bc}$ & $57,67 \mathrm{a}$ & $73,11 a b c$ & $76,00 \mathrm{ab}$ \\
\hline M1X3 & $15,67 \mathrm{a}$ & $21,42 \mathrm{a}$ & $29,22 \mathrm{abc}$ & $63,11 \mathrm{bc}$ & $73,78 \mathrm{abc}$ & $81,00 \mathrm{abc}$ \\
\hline M2X0 & $16,33 a b$ & $20,96 \mathrm{a}$ & $27,44 \mathrm{a}$ & $60,44 a b$ & $70,00 \mathrm{a}$ & $76,00 \mathrm{a}$ \\
\hline M2X1 & $15,56 \mathrm{a}$ & $21,81 \mathrm{a}$ & $30,28 \mathrm{bc}$ & $62,11 \mathrm{~b}$ & $71,56 \mathrm{ab}$ & $80,33 \mathrm{abc}$ \\
\hline M2X2 & $16,00 \mathrm{ab}$ & $21,33 a$ & $31,56 \mathrm{~cd}$ & $64,67 \mathrm{bc}$ & $77,22 \mathrm{bc}$ & $83,33 \mathrm{c}$ \\
\hline M2X3 & $16,80 \mathrm{ab}$ & $21,40 \mathrm{a}$ & $30,00 \mathrm{bc}$ & $61,00 \mathrm{ab}$ & $75,56 \mathrm{abc}$ & $82,00 \mathrm{abc}$ \\
\hline M3X0 & $15,89 \mathrm{a}$ & $21,04 \mathrm{a}$ & $29,60 \mathrm{ab}$ & $61,33 a b$ & $72,78 a b c$ & $76,89 \mathrm{abc}$ \\
\hline M3X1 & $17,89 \mathrm{~b}$ & $23,87 \mathrm{~b}$ & $33,76 \mathrm{~d}$ & $66,78 \mathrm{c}$ & $77,56 \mathrm{c}$ & $82,89 \mathrm{bc}$ \\
\hline M3X2 & $16,56 \mathrm{ab}$ & $21,21 \mathrm{a}$ & $31,13 \mathrm{bc}$ & $64,33 \mathrm{bc}$ & $76,78 \mathrm{bc}$ & $81,33 \mathrm{abc}$ \\
\hline M3X3 & $17,46 \mathrm{ab}$ & $21,20 a$ & $31,20 \mathrm{bc}$ & $64,67 \mathrm{bc}$ & $75,44 a b c$ & $81,11 \mathrm{abc}$ \\
\hline BNJ $\alpha 5 \%$ & 2.12 & 1,73 & 2,35 & 4,29 & 5,78 & 6,71 \\
\hline
\end{tabular}

Keterangan: angka-angka dengan ikutan abjad yang mempunyai kesamaan pada bagian kolom yang mempunyai kesamaan berbeda secara tidak nyata terhadap uji BNJ dengan besaran sebanyak $5 \%$. 
Tabel 1 mengimpletasikan data bahwa ketinggian tumbuhan tomat di usia 7 Hst pada penerapan kombinasi pemberlakuan media tanah, arang sekam dan ditambahkan Poc sebanyak $2 \mathrm{Ml}$ / Liter dengan identitas (M3X1) mempunyai keterbedaan yang nyata dengan rumbukan yang beridentitas (M1X1), (M2X1), (M1X2) dan (M3X0), akan tetapi tidak mempunyai perbedaan yang nyata dengan perlakuan pada tanaman yang beridentitas (M1X0), (M2X3), (M2X2) dan (M3X3), di umur $14 \mathrm{Hst}$ besaran tinggi tanaman tomat (M3X1) berbeda nyata dengan semuah kombinasi perlakuan. Pada 21 HST tinggi tanaman mempunyai keterbedaan yang nyata dengan kombinasi pemberlakuan (M1X1), (M1X2) dan lain dengan sebuah kombinasi pemberlakuan (M1X0), (M2X0). Pada kombinasi perlakuan (M3X1) mempunyai keterbedaan yang nyata dengan semua kombinasi pemberlakuan, antara kombinasai yang beridentitas (M1X0), (M2X0) dan (M3X0) tidak mempunyai keterbedaan yang nyata dengan kombinasi pemberlakuan (M1X3). Di umur $28 \mathrm{Hst}$ pada kombinasi perlakuan dengan identitas (M2X1) mempunyai keterbedaan yang nyata dengan (M3X1), (M1X3), akan tetapi pada kombinasi pemberlakuan tidak mempunyai keterbedaan yang nyata dengan kombinasi perberlakuan (M2X3), (M3X2). Di umur 42 Hst pada kombinasi pemberlakuan (M3X1) mempunyai keterbedaan yang nyata dengan (M2X0), (M2X1) dan (M1X2) akan tetapi tidak mempunyai keterbedaan yang nyata pada kombinasi pemberlakuan (M1X1), (M2X2) dan (M3X2). Di umur 49 Hst pada kombinasi pemberlakuan (M2X2) mempunyai keterbedaan yang nyata dengan (M2X0), (M1X0) dan (M3X1), akan tetapi tidak mempunyai keterbedaan yang nyata pada kombinasi pemberlakuan (M3X1), (M1X3).

\section{Diameter Batang}

Hasil Panen tomat dengan mengacu pada data hasil kegiatan mengalisis ragam mengintegrasikan terdapat sebuah interaksi yang terjadi antara medium tanam dan poc memiliki pengaruh yang besar dan nyata terhadap terhadap besaran diameter batang tanaman di umur $7 \mathrm{Hst}, 14 \mathrm{Hst}$ serta memiliki pengaruh yang lebih besar mengenai ketinggian tumbuhan

tomat di usia $35 \mathrm{Hst}, 42 \mathrm{Hst}$ serta 49 Hst. Sedangkan di usia $21 \mathrm{Hst}$, serta $28 \mathrm{Hst}$ tidak terjadi interaksi yang berarti.

Tabel 2. Pengaruh POC terhadap rerata diameter batang tanaman tomat pada umur 21 dan 28 hst

\begin{tabular}{ccc}
\hline \multirow{2}{*}{ Perlakuan } & $\begin{array}{c}\text { Rerata Diameter Batang Tanaman Umur (HST) } \\
\text { 21 Hst }\end{array}$ & $\mathbf{2 8 ~ H s t}$ \\
\hline X0 & $0,19 \mathrm{a}$ & $0,25 \mathrm{a}$ \\
$\mathbf{X} 1$ & $0,21 \mathrm{~b}$ & $0,27 \mathrm{a}$ \\
$\mathbf{X 2}$ & $0,21 \mathrm{~b}$ & $0,27 \mathrm{a}$ \\
$\mathbf{X 3}$ & $0,20 \mathrm{a}$ & $0,26 \mathrm{a}$ \\
\hline BNJ $\boldsymbol{\alpha}$ & $\mathbf{0 , 0 1 4}$ & $\mathbf{0 , 0 1 6}$ \\
$\mathbf{5 \%}$ & $0,20 \mathrm{a}$ & $0,26 \mathrm{a}$ \\
$\mathbf{M 1}$ & $0,19 \mathrm{a}$ & $0,26 \mathrm{a}$ \\
$\mathbf{M} \mathbf{2}$ & $0,21 \mathrm{a}$ & $0,28 \mathrm{~b}$ \\
$\mathbf{M 3}$ & $\mathbf{0 . 0 1 1}$ & $\mathbf{0 , 0 1 3}$ \\
\hline BNJ $\mathbf{~ 5 \%}$ & Bilangan dengan ikutan abjad yang mempunyai kesamaan pada bagian kolom yang \\
\hline Keterangan: & mempunyai kesamaan berbeda secara tidak nyata terhadap uji BNJ dengan
\end{tabular}

Tabel 2. Mengipletasikan data bahwa di usia 21 Hst, POC (X1) berbeda ukuran secara nyata dengan besaran diameter batang tanaman dengan identitas (X0), (X3), namun demikian, tidak mempunyai keterbedaan yang bersifat nyata mengenai besaran diameter batang di tanaman dengan identitas (X2). Sedangkan di umur 28 Hst dalam arah perlakuan Poc tidak mengintegrasikan adanya perbedaan antara perlakuan.

Media tanam berupa tanah (M1) tidak mempunyai keterbedaan yang bersifat nyata mengenai besaran diameter batang tumbuhan yang menggunakan media penanaman sekam. Hal tersebut dibuktikan dengan data hasil tanam dengan media tanah berindentitas M2 dan sekam tanah berindentitas M3 di umur 21 Hst. Selanjutnya pada penerapan penggunaan media tanam yang berupa arang sekam tanah (M3) mempunyai keterbedaan yang nyata dengan penerapan penggunaan media tanah (M1) serta sekam tanah (M2).

\section{Pengamatan Jumlah Daun (helai)}

Hasil Panen dengan mengacu pada proses menganalisis ragam mengintegrasikan 
terdapatnya sebuah interaksi yang terjadi diantara jenis media serta poc yang memiliki penyebab secara nyata mengenai besaran jumlah daun tumbuhan tomat di usia $14 \mathrm{Hst}$, kemudian $21 \mathrm{Hst}$, kemudian $28 \mathrm{Hst}$, kemudian $35 \mathrm{Hst}$, dan terakhir di usia $49 \mathrm{Hst}$. Pengaruh terbesar jumlah besaran daun tumbuhan tomat terjadi di umur 21 Hst. Namun demikian, di usia $7 \mathrm{Hst}$, kemudian usia $42 \mathrm{Hst}$ disimpulkan tidak ditemukan adanya interaksi berarti.

Tabel 3. Pengaruh POC dan Media Tanam terhadap Jumlah Daun pada Umur 7 dan 42 HST

\begin{tabular}{|c|c|c|}
\hline \multirow{2}{*}{ Perlakuan } & \multicolumn{2}{|c|}{ Rerata Jumlah Daun Tanaman Umur (HST) } \\
\hline & $7 \mathrm{Hst}$ & $42 \mathrm{Hst}$ \\
\hline $\mathbf{X 0}$ & $10,63 \mathrm{a}$ & $33,44 a$ \\
\hline $\mathrm{X} 1$ & $13,26 \mathrm{~b}$ & $35,59 \mathrm{~b}$ \\
\hline $\mathrm{X} 2$ & $13,00 \mathrm{~b}$ & $34,28 a b$ \\
\hline $\mathrm{X} 3$ & $12,78 \mathrm{~b}$ & $34,00 \mathrm{a}$ \\
\hline $\begin{array}{l}\text { BNJ a } \\
5 \%\end{array}$ & 0.82 & 1.64 \\
\hline M1 & $12,11 \mathrm{a}$ & $34,19 a b$ \\
\hline M2 & $12,44 \mathrm{a}$ & $33,72 \mathrm{a}$ \\
\hline M3 & $12,69 \mathrm{a}$ & $35,07 \mathrm{a}$ \\
\hline BNJ $\propto 5 \%$ & 0.64 & 1.29 \\
\hline
\end{tabular}

Keterangan: Dengan ikutan abjad yang mempunyai kesamaan pada bagian kolom yang mempunyai kesamaan berbeda secara tidak nyata terhadap uji BNJ dengan besaran sebanyak $5 \%$.

Tabel 3. Mengintegrasikan sebuah data bahwa di umur 7 Hst Poc (X1) mempunyai keterbedaan yang nyata mengenai jumlah daun tanaman dengan identitas X0, akan tetapi tidak mempunyai keterbedaan yang nyata mengenai jumlah daun tanaman dengan identitas tanaman (X2), (X3). Sedangkan di umur 42 Hst pada bidang perlakuan Poc memiliki keterbedaan yang nyata dengan perlakuan (X1) dan (X3). Selanjutnya, tidak ditemukan keterbedaan yang nyata dengan tanaman (X2), akan tetapi mempunyai keterbedaan yang nyata dengan tanaman $(\mathrm{X} 1)$.

Media tanam Tanah dengan identitas (M1) tidak mempunyai keterbedaan yang nyata mengenai besaran jumlah daun tanaman tomat kaitannya dengan media yang digunakan dalam proses penanaman tumbuhan tomat menggunakan media arang sekam dengan tanah yang beridentitas (M2) dan sekam di umur 7 Hst. Sedangkan pada perlakuan mengenai media tanah, sekam (M3) mempunyai keterbedaan yang nyata dengan sebuah perlakuan pada tanah ( M1) dan arang sekam, serta tanah ( M2).

\section{Pengamatan Luas Daun Tanaman}

Hasil Panen dengan mengacu pada analisis ragam mengintegrasikan adanya interaksi antara jenis media dan poc yang memiliki memiliki penyebab secara nyata mengenai jumlah daun tumbuhan tomat di usia 14 Hst, 21 Hst, serta 42 Hst. Mempunyai penyebab yang sangat signifikan mengenai besaran jumlah daun tumbuhan tomat di usia 21 Hst. Akan tetapi, tidak ditemukan interaksi yang berarti di usia $7 \mathrm{Hst}$, serta $42 \mathrm{Hst}$. 
Tabel 4. Pengaruh POC dan Jenis Media Tanaman terhadap Luas Daun pada Umur 7, 21, 35, 49 HST

\begin{tabular}{|c|c|c|c|c|}
\hline \multirow{2}{*}{ Perlakuan } & \multicolumn{4}{|c|}{ Rerata Luas Daun Tanaman Umur (HST) } \\
\hline & $7 \mathrm{Hst}$ & $21 \mathrm{Hst}$ & $35 \mathrm{Hst}$ & 49 Hst \\
\hline $\mathbf{X O}$ & $11,06 \mathrm{a}$ & $47,31 \mathrm{a}$ & $51,37 \mathrm{a}$ & $64,61 \mathrm{a}$ \\
\hline $\mathbf{X} 1$ & $12,02 \mathrm{a}$ & $55,74 \mathrm{~b}$ & $61,77 \mathrm{~b}$ & $69,21 \mathrm{ab}$ \\
\hline $\mathrm{X} 2$ & $11,79 \mathrm{a}$ & $55,92 \mathrm{~b}$ & $63,29 \mathrm{~b}$ & $70,41 \mathrm{~b}$ \\
\hline X3 & $11,16 \mathrm{a}$ & $56,14 \mathrm{~b}$ & $62,70 \mathrm{~b}$ & $70,58 \mathrm{~b}$ \\
\hline $\begin{array}{c}\text { BNJ } \alpha \\
5 \%\end{array}$ & 1.43 & 3.82 & 5.71 & 4.04 \\
\hline M1 & $11,02 \mathrm{a}$ & $52,21 \mathrm{a}$ & 58,89 a & $67,77 \mathrm{a}$ \\
\hline M2 & $11,30 \mathrm{a}$ & $52,68 \mathrm{a}$ & $59,01 \mathrm{a}$ & 66,93 a \\
\hline M3 & $12,21 \mathrm{~b}$ & $56,45 b$ & $61,45 \mathrm{a}$ & $71,40 \mathrm{~b}$ \\
\hline BNJ $\propto 5 \%$ & 1.12 & 2.99 & 4.48 & 3.16 \\
\hline
\end{tabular}

Keterangan: Dengan ikutan abjad yang mempunyai kesamaan pada bagian kolom yang mempunyai kesamaan berbeda secara tidak nyata terhadap uji BNJ dengan besaran sebanyak 5\%.

Tabel 4. Memaparkan data bahwa di umur 7 Hst Poc yang sudah mendapatkan perlakuan tidak ditemukan adanya perbedaan nyata nyata. Sedangkan di umur $21 \mathrm{Hst}$ Poc dengan identitas $(X)$ mempunyai keterbedaan yang nyata mengenai luas daun tanaman tomat dengan (X0), akan tetapi, tidak mempunyai keterbedaan yang nyata mengenai luas daun tanaman tomat dengan identitas (X2) dan (X3). Selanjutnya, di umur 35 Hst Poc yang beridentitas (X1) memiliki keterbedaan yang nyata mengenai luas daun tanaman tomat dengan (X0), akan tetapi, tidak mempunyai keterbedaan yang nyata mengenai luas daun tanaman dengan identitas (X2) dan (X3). Terakhir di umur 49 Hst (X0) mempunyai keterbedaan yanh nyata mengenai luas daun tanaman tomat dengan identitas (X2), dan (X3), sedangkan untuk tingkat keterbedaannya tidak ditemukan terjadi pada identitas (X1).

Media tanam di umur 7 Hst dengan menggunakan media sekam, tanah yang beridentitas (M3) mempunyai tingkat keterbedaan yang nyata mengenai luas daun tanaman tomat dengan media tanah yang beridentitas (M1) dan media arang sekam yang beridentitas (M2). Media tanam di umur 21 Hst dengan penerapan media sekam dengan tanah yang beridentitas (M3) mempunyai keterbedaan yang nyata mengenai luas daun tanaman tomat dengan media tanah yang beridentitas (M1) dan media arang sekam yang beridentitas (M2). Selanjutnya, di umur 35 Hst tepatnya pada pemberlakuan media tanam sekam, tanah yang beridentitas (M3), media tanah yang beridentitas (M1), dan media arang sekam, tanah dengan identotas (M2) tidak memiliki keterbedaan secara nyata. Terakhir, di umur 49 Hst penerapan media sekam dengan tanah yang beridentitas (M3) mempunyai keterbedaan yang nyata mengenai luas daun tanaman tomat dengan media tanah yang beridentitas (M1) dan media arang sekam yang beridentitas (M2).

\section{Pengamatan Jumlah Cabang Tanaman}

Tabel 5. Pengaruh POC dan Jenis Media Tanam Terhadap Jumlah Cabang Tanaman

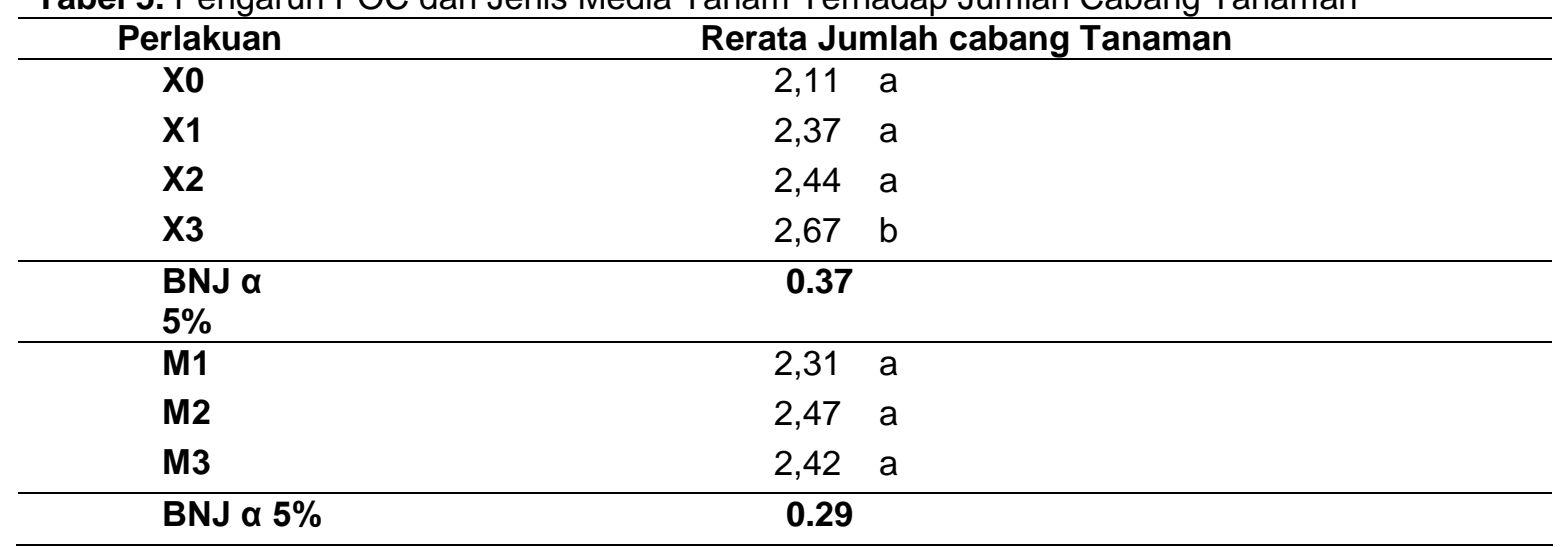

Keterangan: Dengan ikutan abjad yang mempunyai kesamaan pada bagian kolom yang mempunyai kesamaan berbeda secara tidak nyata terhadap uji BNJ dengan besaran sebanyak $5 \%$. 
Tabel 11. Memaparkan sebuah data yang mengintegrasikan bahwa pada besaran jumlah cabang Poc $6 \mathrm{~mL} /$ Liter yang beridentitas (X3) mempunyai keterbedaan yang nyata mengenai jumlah cabang tanaman tomat dengan Poc yang tanpa menerapkan penggunaan Ratu Biogen yang beridentitas (X0), menerapkan penggunaan Poc $2 \mathrm{~mL} / \mathrm{Liter}$ yang beridentitas (X1) dan yang menerapkan penggunaan Poc $4 \mathrm{ml} /$ Liter dengan identitas (X2).

Media tanam tanah yang beridentitas (M1) tidak mempunyai keterbedaan yang nyata mengenai besaram jumlah cabang tanaman tomat dengan media tanam tanah yang beridentitas (M1), dengan keterangan lebih detail bahwa tanah mempunyai identitas (M2) dan media arang sekam, serta tanah yang mempunyai identitas (M3).

\section{Pengamatan Jumlah Buah Panen}

Hasil Panen dengan mengacu pada hasil kegiatan analisis ragam (ANOVA) di taraf $5 \%$ telah menunjukkan adanya interaksi pada hasil akhir, dengan keterangan bahwa mempunyai keterbedaan yang nyata antara penerapan macam media dan poc terhadap besaran jumlah buah di fase panen ke dua.

Tabel 6. Pengaruh POC dan Jenis Media Tanam Terhadap Hasil Jumlah Panen

\begin{tabular}{|c|c|c|c|c|c|c|c|c|}
\hline \multirow[t]{2}{*}{ Perlakuan } & \multicolumn{8}{|c|}{ Rerata Jumlah Buah Panen } \\
\hline & Panen & & Pane & & Panen & & Panen 5 & \\
\hline $\mathbf{X O}$ & 0,87 & $\mathrm{a}$ & 2,26 & $\mathrm{a}$ & 2,63 & $\mathrm{a}$ & 2,59 & $\mathrm{a}$ \\
\hline X1 & 1,11 & a & 2,37 & a & 2,48 & a & 2,37 & a \\
\hline $\mathrm{X} 2$ & 1,30 & a & 2,56 & a & 2,85 & a & 2,44 & a \\
\hline $\mathrm{X} 3$ & 1,28 & a & 2,74 & a & 2,89 & a & 2,63 & a \\
\hline $\begin{array}{l}\text { BNJ a } \\
5 \%\end{array}$ & 0.47 & & 0.48 & & 0.51 & & 0.64 & \\
\hline M1 & 1,08 & $\mathrm{a}$ & 2,42 & a & 2,53 & $\mathrm{a}$ & 2,50 & $\mathrm{a}$ \\
\hline M2 & 1,18 & a & 2,33 & a & 2,72 & a & 2,42 & a \\
\hline M3 & 1,15 & $\mathrm{a}$ & 2,69 & a & 2,89 & $\mathrm{a}$ & 2,61 & $\mathrm{a}$ \\
\hline $\begin{array}{l}\text { BNJ a } \\
5 \%\end{array}$ & 0.37 & & 0.38 & & 0.40 & & 0.50 & \\
\hline
\end{tabular}

Keterangan: Dengan ikutan abjad yang mempunyai kesamaan pada bagian kolom yang mempunyai kesamaan berbeda secara tidak nyata terhadap uji BNJ dengan besaran sebanyak $5 \%$.

Tabel 6. Memaparkan sebuah data yang mengintegrasikan bahwa adanya kombinasi perlakuan telah mengakibatkan jumlah buah tomat pada fase panen pertama tidak memperlihatkan implikasi perbedaan yang nyata antara perlakuan. Selanjutnya pada kombinasi perlakuan besaran jumlah buah tomat pada fase panen ke tiga tidak memperlihatkan perbedaan yang nyata antara perlakuan. Pada kombinasi perlakuan besaran jumlah buah tomat pada fase panen keempat tidak memperlihatkan perbedaan yang nyata antara perlakuan. Pada kombinasi perlakuan besaran jumlah buah tomat pada fase panen ke lima tidak memperlihatkan perbedaan yang nyata antara perlakuan.
Media tanam tanah yang beridenti tas (M1) tidak mempunyai keterbedaan yang nyata mengenai jumlah buah tomat pada fase panen pertama dengan media tanah yang beridentitas (M1), arang sekam, media tanah yang beridentitas (M2) dan sekam, serta media tanah yang beridentitas (M3).

\section{Pengamatan Berat Buah Panen}

Hasil Panen dengan mengacu pada hasil kegiatan analisis ragam (ANOVA) di taraf $5 \%$ telah menunjukkan adanya interaksi pada hasil akhir mengenau macam media yang dipergunakan dan POC terhadap besaran jumlah buah tomat pada fase panen ketiga. 
Tabel 7. Pengaruh POC dan Jenis Media Tanam Terhadap Berat Buah

\begin{tabular}{lrlrlrlll}
\hline \multirow{2}{*}{ Perlakuan } & \multicolumn{7}{c}{ Rerata Berat Buah Panen } \\
\cline { 2 - 9 } & Panen 1 & \multicolumn{1}{c}{ Panen 2 } & Panen 4 & \multicolumn{3}{c}{ Panen 5 } \\
\hline X0 & $20,44,41$ & a & a & 52,30 & a & 45,67 & a \\
X1 & 36,46 & a & 78,93 & a & 75,67 & b & 52,41 & a \\
X2 & 44,61 & bc & 92,56 & bc & 82,37 & b & 60,22 & ab \\
X3 & 58,83 & c & 99,30 & c & 100,96 & c & 82,85 & b \\
\hline BNJ a & & & & & & & & \\
5\% & $\mathbf{1 6 . 1 6}$ & $\mathbf{1 6 . 5 9}$ & $\mathbf{1 4 . 9 9}$ & & $\mathbf{2 0 . 3 5}$ & \\
\hline M1 & 36,04 & a & 92,50 & b & 68,89 & a & 63,36 & a \\
M2 & 41,72 & a & 76,50 & a & 75,64 & a & 57,11 & a \\
M3 & 42,50 & a & 80,14 & a & 88,94 & b & 60,39 & a \\
\hline BNJ a 5\% & $\mathbf{1 2 . 6 6}$ & $\mathbf{1 3 . 0 0}$ & $\mathbf{1 1 . 7 4}$ & $\mathbf{1 5 . 9 4}$ & \\
\hline
\end{tabular}

Keterangan: Dengan ikutan abjad yang mempunyai kesamaan pada bagian kolom yang mempunyai kesamaan berbeda secara tidak nyata terhadap uji BNJ dengan besaran sebanyak $5 \%$.

Pengamatan hasil Berat buah terdapat pada perlakuan pemberian tanah, arang sekam dengan pemberian pupuk cair 6 $\mathrm{mL} /$ Liter. Sedangkan perlakuan terendah diajukan pada perlakuan pemberian media tanah dan tampah pemberian pupuk cair ratu biogen pada pengamatan panen pertama,ke dua, keempat dan kelima. Hal ini diduga karena pemberian media dan pupuk organik cair yang optimal mampu menyediakan unsur hara fosfor dan kalium yang sesuai dengan kebutuhan tanaman tomat dalam berat buah. Sesuai dengan pendapat Anonim (2011) menyatakan bahwa berat dan kualitar buah pada fase generatif akan di pengaruh oleh ketersedian unsur hara kalium $(\mathrm{K})$ sedangka unsur hara fosfor $(P)$ berperan dalam pembentukan bunga dan buah bagi tanaman . Ketersediaan unsur hara yang cukup akan memacu pertumbuhan pada fase generatif tanaman, sehingga dapat mempercepat prese pertumbuhan tanaman dan menghasilkan berat buah per tanaman yang lebih besar.

\section{KESIMPULAN}

1. Dalam penelitian yang kami lakukan, kami menemukan adanya interaksi secara nyata pada ringkatan tinggi tanaman tomat, besaran jumlah buah pada setiap tanaman tomat, besaran berat buah di seriap umur, dengan berbagai kombinasi yang terbaik didapatkan adalah dengan menerapkan penggunaan media tanah, arang sekam dan pupuk organik cair $6 \mathrm{~mL} /$ Liter pada penanaman tomat.

2. Pemberlakuan media tanam berupa tanah, media arang sekam mengintegrasikan bahwa media tersebur merupkan yang terbaik jika dibandingkan dengan pemberlakuan media tanam berupa tanah dan tanpa menerapkan penggunaan pupuk organik cair dalam proses penanaman tumbuhan tomat.

3. Pemberlakuan pupuk organik cair sebanyak

$6 \mathrm{~mL} /$ Liter telah memberikan dampak yang sangat signifikan mengenai tinggi tumbuhan tomat di usia $7 \mathrm{Hst}, 14 \mathrm{Hs}, 35 \mathrm{Hst}, 42 \mathrm{Hst}, 49$ Hst dan besaran jumlah daun untuk semua umur kecuali di usia $7 \mathrm{Hst}, 18 \mathrm{Hst}$, dan $42 \mathrm{Hst}$, jumlah hasil panen pada fase pertama, kedua, ketiga, keempat, serta kelima. Serta besaran berat buah pada fase panen pertama, kedua, ketiga, keempat, serta kelima per panen

\section{DAFTAR PUSTAKA}

Alatas, Salim. 2013. Dampak Konvergensi Media Terhadap Akulturasi Budidaya

Amilia, Y. 2011. Penggunaan Pupuk Organik Cair Untuk Mengurangi Dosisi anakan Tumih (Combretocarpus rotundatus (Miq). Danser). Jurnal Silvikultur Tropika 3 (2) :81 -84.

Anonim. 2011. Budidaya Tanaman Tomat. Wikipedia bahasa Indonesia, ensiklopedia Bebas. ( Diakses 18 Agustus 2018).

Badan Pusat Statistik. 2012. Produksi Tomat, Tahun 2012. http://www.bps.go.id. (DiaksesTanggal 13 juni 2014).

Prayugo, 2007. Pengaruh Jenis Media Tanam Serta Drainase Terawat. Gramedia. Jakarta

Parman, 2007. Pengaruh Jenis Media Tanam Pemberian Pupuk Organik Cair Terhaap Pertumbuhan Tanaman Tomat.Institue Pertanian Bogor.Bogor.

Rianti,2009.Jenis Media Tanam Yang Ideal.Gramedia. Jakarta

Setiadi, 2008. Manfaat Tomat Sebagai Bahan Kosmetik. PT. Gramedia Pustaka Utama. Jakarta

Surtina, 2009. Penggunaan Pupuk Organik Cair Terhadap Pertumbuhan Dan Hasil Tanaman Tomat. Pengantar IImu Tanah Jakarta 